Article

\title{
Fish Oil and Fish Meal Production from Urban Fisheries Biomass in Japan
}

\author{
Atsushi Ido *(D) and Mika Kaneta \\ Graduate School of Agriculture, Ehime University, 3-5-7, Tarumi, Matsuyama 790-8566, Japan; \\ kaneta.mika.vf@ehime-u.ac.jp \\ * Correspondence: ido@agr.ehime-u.ac.jp; Tel.: +81-89-946-3684
}

Received: 2 April 2020; Accepted: 16 April 2020; Published: 20 April 2020

check for updates

\begin{abstract}
Finding an alternative feed source for the replacement of fish oil (FO) and fish meal (FM) produced from whole fish has been an important issue for realizing sustainable aquaculture. In this study, fishery by-products generated in the distribution phase, known as urban fisheries biomass (UFB), were focused on. The quality parameter and nutrient components of FO and FM from UFB were analyzed. Although crude FO produced from UFB showed relatively poor quality properties, the refinement process made an improvement of the quality to make it comparable to commercially available FO. There is no big variation in several samples in fatty acid profiles of FO and amino acid profiles of FM, and they seem to be able to replace FO and FM from whole fish in the diet for cultured fish. The utilization of UFB should be promoted in economic and ecologic aspects; however, in use of the FM, there remains a risk of intra-species recycling that might lead to transmissible spongiform encephalopathy. Furthermore, we must take into consideration the possibility of contamination of fishery products from at-risk species and illegal, unreported, and unregulated (IUU) fisheries due to the lack of regulations in Japan.
\end{abstract}

Keywords: aquaculture; fish feed; fisheries by-products; food waste; traceability; oil refinement

\section{Introduction}

To supply nutrition to help end global hunger, aquaculture is a key method of food production, and world aquaculture production is rapidly growing. Fish oil (FO) and fish meal (FM) are essential dietary sources of cultured fish. Pelagic fish have mainly been used for FO and FM production, and 30 million tonnes of wild-caught fish have been used for FO and FM [1]. Furthermore, 74\% of FO and $68 \%$ of FM were used in aquaculture in 2012 [2]. Fishing pressure on pelagic fish has been a serious concern in marine ecosystems [3]. Since the usage of fish feeds for aquaculture is estimated to increase until 2025 in spite of the limited supply of FO and FM from wild fish, the prices of FO and FM have been steadily increasing [2]. Although various alternative feed sources to FO and FM have been studied, such as plants [4-6], terrestrial animals [6-8], insects [9-12], and microalgae [13], they do not necessarily meet the nutritional requirements of cultured carnivorous fish [14].

Food waste must be reduced globally to meet sustainable development goals, as well as supplying nutrition. The edible portion of fish is $50 \%-70 \%$ of the whole body [15], and the other parts of fish, that is, the head, bones, gut, and blood, are the by-products (BPs) of fish processing. From 40 to 60 million tonnes of fishery BPs are estimated to arise from wild-caught and cultured fish [16,17]. FM from BPs contains a well-balanced amino-acid composition, and FO from BPs is rich in omega-3 polyunsaturated fatty acids, namely, eicosapentaenoic acid (EPA) and docosahexaenoic acid (DHA) [18]. Nowadays, 1.5 million tonnes of BPs are used globally for FO and FM production; although that accounts for $33 \%$ of total FM production and 23\% of total EPA and DHA in FO production in the world, there are potentially $35,837,000$ tonnes of unused biomass ( $86.3 \%$ of total BPs by calculation) [17]. 
The utilization of fishery BPs is clearly essential for the establishment of a sustainable society because of their great potential. To date, utilization of BPs in salmonid aquaculture has been reported in Scotland [16] and Norway [19]. On the other hand, in many Asian countries, it is difficult to obtain BPs from the aquatic food industry, except for the tuna canning sector in Thailand [20].

People in Japan have traditionally eaten various kinds of fish, and a utilization system of BPs has been uniquely developed. In Japan, 844,909 tonnes of material were used for the production of FO and FM, and 79.4\% of the total material (670,987 tonnes) was BPs in 2018 [21]. The quantity of fishery BPs was investigated in each phase of the seafood supply chain in Japan in the early 2000s [22]. According to the study, 667,000 tonnes (31.7\%) of BPs came from fishery processors (upstream of the supply chain), while 1,438,000 tonnes (68.3\%) came from wholesale, retail, and restaurants (downstream). Kitchen waste was not included in the BPs.

BPs not only from the upstream but also from the downstream have been collected for FO and FM production in Japan. Nevertheless, there have been few studies on the FO and FM with that system in this decade. The purpose of this article is to compare FO and FM production from BPs in Japan with those in other regions using case studies. Moreover, we would like to focus on not only the qualities of FO and FM from BPs but the contribution of the system to sustainable aquaculture as well.

\section{Materials and Methods}

\subsection{Fish Oil and Fish Meal from Urban Fisheries Biomass}

Crude FO and FM for this study were kindly provided by Sanki Shiryo Kogyo Co., Ltd. (Soka, Japan). For one day, a total of 400-500 tonnes of fishery BPs were collected from over 10,000 suppliers located mainly in the Kanto area, Japan. They were heated at $90-95{ }^{\circ} \mathrm{C}$ for $20 \mathrm{~min}$ in a cooker (Atlas-Stord AS, Rødovre, Denmark), and were separated in the liquid phase from sediment with a screw decanter centrifuge (TOMOE Engineering Co., Ltd., Tokyo, Japan). The liquid phase was further separated into crude FO from fine solids with a three-layered centrifuge (Alfa Laval, Lund, Sweden) at $90^{\circ} \mathrm{C}$. Components other than crude oil were gathered to be dried with $160-180{ }^{\circ} \mathrm{C}$ superheated steam for $100 \mathrm{~min}$ in a dryer (Atlas-Stord AS, Rødovre, Denmark), and FM was obtained. Five samples of crude FO and FM were used for analysis, and each sample was produced on a different day.

\subsection{Refinement Process of Fish Oil}

Crude FO was refined through deoxidization, water-washing, and a decolorization process, as described by previous studies $[23,24]$. Briefly, the crude FO was mixed with sodium hydroxide at over $65{ }^{\circ} \mathrm{C}$ for over $10 \mathrm{~min}$. The oil was washed with tap water and was left until water and oil layers emerged. The water layer was removed from the bottom of the tank. In the decolorization process, approximately $5 \%$ of activated clay was added to the oil at over $70^{\circ} \mathrm{C}$ for $20 \mathrm{~min}$. The refined oil was obtained with a filter press.

\subsection{Analysis of Fish Oil}

Five different lots of crude, deoxidized, water-washed, and decolorized oil samples for analysis were kindly provided by Nikko Oil \& Fat Co., Ltd. (Amagasaki, Japan). Commercially available cod liver oil, extracted from Alaska pollock (Theragra chalcogramma), was used as the control in the study. The samples were divided into sealed glass bottles at the required volume and kept frozen at $-20^{\circ} \mathrm{C}$ until analysis.

\subsubsection{Acid Value, Peroxide Value, p-Anisidine Value, and Total Oxidation Value}

The acid value $(\mathrm{AV})$, peroxide value (POV), and $p$-Anisidine value $(p-\mathrm{AV})$ of oils were analyzed in accordance with the standard methodologies in Japan [25]. Briefly, for the analysis of AV, oil samples were dissolved into a neutralized solution of diethyl ether:ethanol (1:1), and AV (mg KOH/g) was determined by titration with $0.1 \mathrm{~mol} / \mathrm{L}$ potassium hydroxide $(\mathrm{KOH})$. For the analysis of POV, 
gas in a flask containing oil samples was dissolved into $10 \mathrm{~mL}$ of chloroform, and $15 \mathrm{~mL}$ of acetic acid was changed into nitrogen gas; then, saturated potassium iodine was added, and mixed slowly for $1 \mathrm{~min}$. After that, distilled water was immediately added and mixed, and POV (meq of $\mathrm{O}_{2} / \mathrm{kg}$ ) was determined by titration with $0.01 \mathrm{~mol} / \mathrm{L}$ sodium thiosulfate in the presence of starch solution. For the analysis of $p$-AV, $0.25 \mathrm{~g} / 100 \mathrm{~mL} p$-Anisidine-acetate solution was added to oil samples dissolved into 2,2,4-Trimethylpentane and left for $10 \mathrm{~min}$. p-AVs were calculated with absorbance at $350 \mathrm{~nm}$. The analyses were repeated three or six times for one sample. The total oxidation (TOTOX) values were calculated as TOTOX $=(2 \times \mathrm{POV})+p$-AV.

\subsubsection{Thiobarbituric Acid Reactive Substances Value}

Thiobarbituric acid reactive substance (TBAR) values of oils were analyzed following the standard method [26]. A total of 20-30 mg of oil was placed into a screw-capped glass tube, and $1.5 \mathrm{~mL}$ of acetic acid buffer ( $20 \%$ acetic acid adjusted pH 3.5 with $10 \mathrm{~N} \mathrm{NaOH}), 1.5 \mathrm{~mL}$ of Thiobarbituric acid reagent ( $0.8 \mathrm{~g}$ TBA $/ 100 \mathrm{~mL}$ distilled hot water), $0.05 \mathrm{~mL}$ of $0.8 \%$ dibutylhydroxytoluene dissolved in acetic acid, $0.2 \mathrm{~mL}$ of $8.1 \%$ sodium dodecyl sulfate solution, and $1 \mathrm{~mL}$ of distilled water were added. The reaction tubes were cooled at $5{ }^{\circ} \mathrm{C}$ for $1 \mathrm{~h}$ and inserted into boiling water for another hour. Tubes were cooled with water, then $1 \mathrm{~mL}$ of distilled water and $5 \mathrm{~mL}$ of 1-butanol:pyridine (15:1) solution were added; this was then centrifuged at $3000 \mathrm{rpm}$ for $10 \mathrm{~min}$. The absorbance of the upper layers at $532 \mathrm{~nm}$ was measured, and TBAR values ( $\mu \mathrm{mol} / \mathrm{g}$ oil sample) were calculated.

\subsubsection{Oxidative Stability}

The stability of oil to oxidation was determined by the Rancimat method [27] with 892 Professional Rancimat (Metrohm, Herisau, Switzerland). Samples weighing $3 \mathrm{~g}$ were kept at $100^{\circ} \mathrm{C}$ until maximum conductivity, at $150 \mu \mathrm{S} / \mathrm{cm}$, with constant gas flow, $20.0 \mathrm{~L} /$ hour. Induction times were calculated with the computer program StabNet (Metrohm, Herisau, Switzerland). The analysis of control oil was repeated four times, and those of test oils were repeated twice.

\subsubsection{Fatty Acid Profile}

Fatty acids in oil samples were prepared with hydrolysis and extracted with diethyl ether:petroleum ether (1:1). Gas chromatograph GC-2010 (Shimadzu Corporation, Kyoto, Japan) and Agilent J\&W column DB-23 (Agilent Technologies Inc., Santa Clara, CA, USA) were used for analysis with a method described in the food-labelling standards by the Consumer Affairs Agency of Japan [28]. Fatty acids were identified with Supelco 37 Component FAME Mix (Sigma-Aldrich Co. LLC, St. Louis, MO, USA).

\subsection{Analysis of Fish Meal}

Five different lots of fish meal samples for proximate composition and amino-acid profile were supplied by Sanki Shiryo Kogyo Co., Ltd. (Soka, Japan). Commercially available fish meal made from anchoveta (Engraulis ringens), comprising 65\% crude protein, was used for control in the study. Proximate compositions and amino-acid profiles of the samples were analyzed following the Association of Analytical Communities (AOAC) methods [29]. The content of crude protein was analyzed using the Kjeldahl method. Kjeltab containing potassium sulfate was added to the ground samples, and samples were digested in a block heater (Tecator Digestion Systems 2520, FOSS, Hillerød, Denmark). Nitrogen content was automatically analyzed using an autoanalyzer (Kjeltec 8400, FOSS, Hillerød, Denmark). The nitrogen-protein conversion factor was 6.25 for the calculation of crude protein from the nitrogen content. Crude fat was analyzed using the Soxhlet extraction method. Petroleum ether was used as the solvent for extraction from the ground samples in an automated extractor (SoxtecTM 8000, FOSS, Hillerød, Denmark). Ash was analyzed using an electric furnace (MMF-1, AS ONE, Osaka, Japan). The analyses were repeated two times per sample. Proteinogenic amino acids in the meal samples were analyzed using an automated amino acid analyzer (Shimadzu, Kyoto, Japan) after hydrochloric hydrolysis with sodium chloride. For methionine and cystine, the samples were oxidized 
with performic acid prior to hydrochloric hydrolysis. For tryptophan, samples were prepared with barium hydroxide octahydrate and thiodietylene glycol before hydrolysis with sodium chloride and analysis with high-performance liquid chromatography (HPLC). Histamine and volatile basic nitrogen (VBN) in fish meal produced by Sanki Siryo Kogyo Ltd. were analyzed almost every month in the 2018-2019 period. The content of histamine was analyzed with HPLC [30], and VBN was analyzed in accordance with a standard analysis method for feed [31].

\subsection{Statistical Analysis}

Statistically significant differences were identified by Steel-Dwass multiple comparison test as a post hoc test after a Kruskal-Wallis test. The tests were conducted with $\mathrm{R}$ software (https://www.r-project.org).

\section{Results}

\subsection{Urban Fisheries Biomass in Japan}

The relationship between BP quantity and population at the time is shown in Figure 1; a strong correlation was observed between the quantity of BPs downstream and the population in each area $\left(R^{2}=0.78\right)$. Therefore, these BPs could be called the "urban fisheries biomass" (UFB).

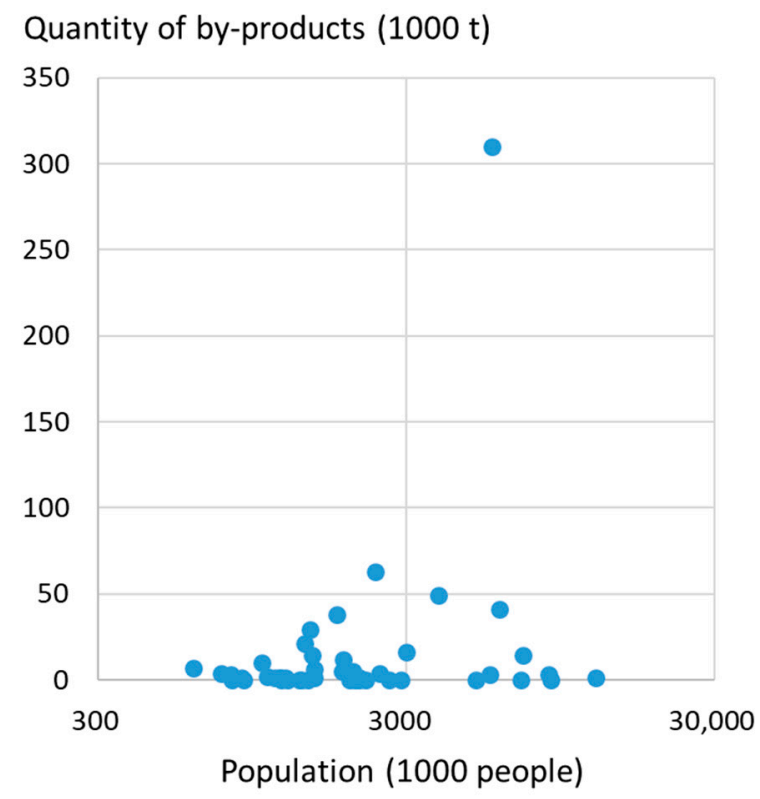

(a)

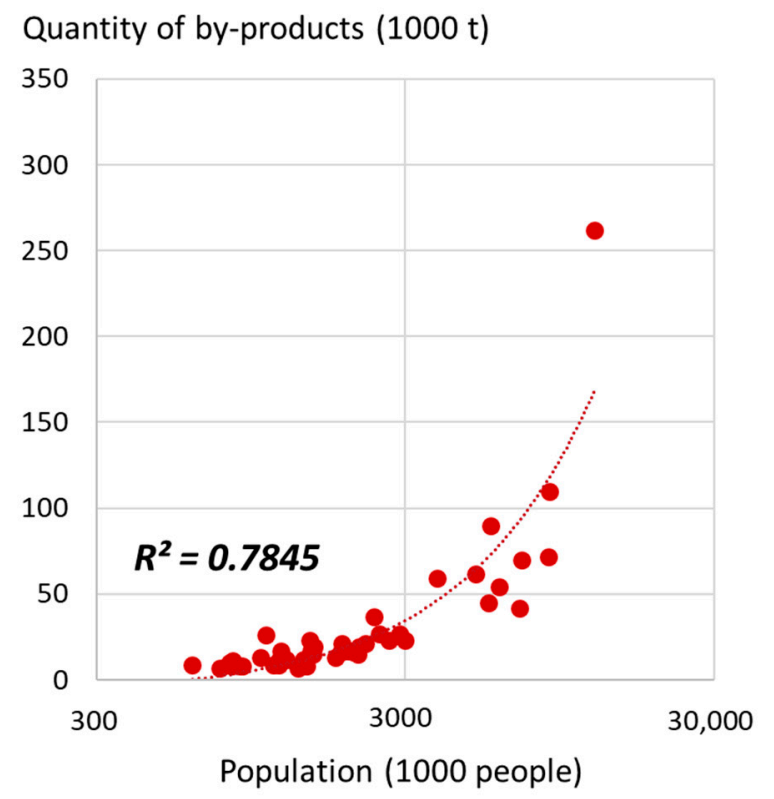

(b)

Figure 1. Correlation between the quantity of by-products and the population in each area in Japan. (a) By-products from upstream, and (b) from downstream of the seafood supply chain. Quantity of by-products in each area was obtained from the previous study [22], and the population data were from statistics of the Japanese government [32].

Since BPs in Japan have a possibility to include those from fish at-risk species, we conducted a risk assessment of the contamination. Fish species listed on the government statistics of fisheries and trade and indicated as Critically Endangered (CR) or Endangered (EN) on the International Union for Conservation of Nature (IUCN) red list at present were the southern bluefin tuna (Thunnus maccoyii) [33] and the Japanese eel (Anguilla japonica) [34]. The contamination risk of two species was calculated from the trading volume that these two species accounted for, and was estimated to be $0.63 \%$ (Table 1 ). 
Table 1. Risk assessment of the contamination of fishery by-products from species at risk in urban fisheries biomass in Japan.

\begin{tabular}{ccccc}
\hline & $\begin{array}{c}\text { Total Amount of } \\
\text { Fish }^{\mathbf{1}}\end{array}$ & $\begin{array}{c}\text { Southern Bluefin } \\
\text { Tuna (Thunnus } \\
\text { maccoyii) }\end{array}$ & $\begin{array}{c}\text { Japanese Eel } \\
\text { (Anguilla } \\
\text { japonica) }\end{array}$ & $\begin{array}{c}\text { Contamination } \\
\text { Risk (\%) }\end{array}$ \\
\hline Wild-catch production ( $\mathrm{t}$ ) & $2,715,220$ & 4072 & 71 & 0.15 \\
Aquaculture production $(\mathrm{t})$ & 284,472 & 0 & 20,979 & 7.37 \\
Import of live fish and & $3,765,865$ & 10,362 & 6816 & 0.46 \\
fishery products ( $\mathrm{t})$ & $6,765,557$ & 14,434 & 27,866 & 0.63 \\
\hline Total production $(\mathrm{t})$ &
\end{tabular}

${ }^{1}$ Since the by-products of the pufferfish were not collected for biomass because of their toxin, productions of pufferfish were excluded. Data are from the government statistics of $2017[35,36]$.

\subsection{Quality of Fish Oil from Urban Fisheries Biomass}

We analyzed the quality parameters of FO from UFB to be compared with those of control FO from cod liver. Although crude oil from UFB showed relatively higher AV, POV, $p$-AV, and TOTOX values than those of control cod-liver oil, their values significantly decreased through the refinement process (Table 2). Consequently, the quality of decolorized oil was comparable or better than that of the control oil in terms of these parameters. TBAR values decreased following the deoxidization process as well, but even crude oil represented lower TBAR values than the control oil. On the whole, the quality of FO from UFB seemed to become comparable through the refinement process with control FO.

Table 2. Chemical properties of fish oil from urban fisheries biomass through the refinement process.

\begin{tabular}{cccccc}
\hline Oil Samples & $\begin{array}{c}\text { AV (mg } \\
\text { KOH/g) }\end{array}$ & $\begin{array}{c}\text { POV (meq of } \\
\text { O2/kg) }\end{array}$ & $\boldsymbol{p - A V}$ & TOTOX Value & $\begin{array}{c}\text { TBARs } \\
(\mu \mathbf{m o l} / \mathbf{g})\end{array}$ \\
\hline Crude & $4.25 \pm 0.39^{\mathrm{a}}$ & $5.89 \pm 0.94^{\mathrm{a}}$ & $24.99 \pm 1.80^{\mathrm{a}}$ & $36.77 \pm 2.58^{\mathrm{a}}$ & $1.09 \pm 0.09^{\mathrm{a}}$ \\
Deoxidized & $0.12 \pm 0.09^{\mathrm{b}}$ & $2.56 \pm 0.81^{\mathrm{b}}$ & $27.12 \pm 5.19^{\mathrm{a}}$ & $32.23 \pm 4.25^{\mathrm{a}}$ & $0.77 \pm 0.14^{\mathrm{b}}$ \\
Water-washed & $0.17 \pm 0.06^{\mathrm{b}}$ & $1.56 \pm 0.36^{\mathrm{b}}$ & $15.62 \pm 3.25^{\mathrm{b}}$ & $18.73 \pm 2.76^{\mathrm{b}}$ & $0.69 \pm 0.08^{\mathrm{b}}$ \\
Decolorized & $0.35 \pm 0.09^{\mathrm{b}}$ & $1.04 \pm 0.13^{\mathrm{c}}$ & $18.16 \pm 1.78^{\mathrm{b}}$ & $20.25 \pm 1.85^{\mathrm{b}}$ & $0.60 \pm 0.07^{\mathrm{b}}$ \\
\hline Cod liver oil & 0.49 & 7.09 & 25.19 & 39.37 & 1.38 \\
\hline
\end{tabular}

Note: AV—acid value; POV—- peroxide value; $p$ - AV— $p$-Anisidine value; TOTOX value—total oxidation value; TBARs-thiobarbituric acid reactive substances. Numbers represent means \pm standard deviations among five different lots $(n=5)$. Different letters $(a-c)$ in the same column denote statistically significant differences according to the Steel-Dwass multiple comparison test as a post hoc test after a Kruskal-Wallis test $(p<0.05)$.

To clarify the effect of the refinement process on oil stability, we compared the oxidative stability of crude oil, water-washed oil, and decolorized oil at $100^{\circ} \mathrm{C}$. Oxidative stability was significantly higher after the deoxidization and water-wash process. The decolorized process did not affect stability (Figure 2). 


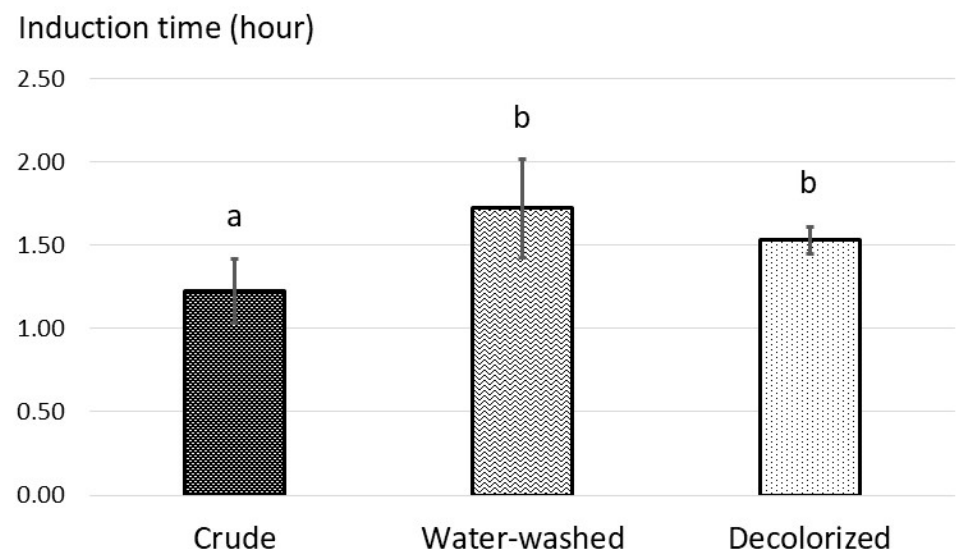

Figure 2. Oxidative stability of fish oil from urban fisheries biomass. $n=8$ (two analyses of four different samples). Error bars represent standard deviations. Different letters $(a, b)$ denote statistically significant differences according to the Steel-Dwass multiple comparison test as a post hoc test after a Kruskal-Wallis test $(p<0.01)$.

The fatty-acid profiles of refined (decolorized) FO from UFB is shown (Table 3). There was little variation among the five samples made from independent UFB on different days. In comparison with the cod liver oil, the refined FO contained more DHA but less EPA.

Table 3. Fatty-acid compositions in refined fish oil from urban fisheries biomass (UFB).

\begin{tabular}{|c|c|c|c|}
\hline $\begin{array}{l}\text { Components } \\
\text { (\% Fatty Acids) }\end{array}$ & \multicolumn{2}{|c|}{ Refined Oil from UFB } & Cod Liver Oil \\
\hline \multicolumn{4}{|c|}{ Saturated fatty acid } \\
\hline 17:0 & 0.5 & \pm 0.0 & 0.1 \\
\hline $18: 0$ & 4.4 & \pm 0.1 & 2.9 \\
\hline $20: 0$ & 0.2 & \pm 0.0 & 0.1 \\
\hline \multicolumn{4}{|c|}{ Monounsaturated fatty acid } \\
\hline $16: 1$ & 5.5 & \pm 0.1 & 8.9 \\
\hline $16: 2$ & 0.9 & \pm 0.1 & 1.0 \\
\hline \multirow{2}{*}{\multicolumn{4}{|c|}{ Polyunsaturated fatty acid }} \\
\hline & & & \\
\hline $18: 1 n-9$ & 21.7 & \pm 0.2 & 16.9 \\
\hline $20: 1 n-9$ & 2.7 & \pm 0.0 & 4.5 \\
\hline $22: 1 n-9$ & 0.5 & \pm 0.0 & 1.5 \\
\hline $\begin{array}{l}24: 1 n-9 \\
\omega-7\end{array}$ & 0.7 & \pm 0.0 & 0.9 \\
\hline $\begin{array}{l}18: 1 \mathrm{n}-7 \\
\omega-6\end{array}$ & 3.3 & \pm 0.0 & 6.1 \\
\hline $18: 2 n-6$ & 4.9 & \pm 0.2 & 1.6 \\
\hline $18: 3 n-6$ & 0.1 & \pm 0.0 & - \\
\hline $20: 2 n-6$ & 0.4 & \pm 0.0 & 0.3 \\
\hline $20: 3 n-6$ & 0.1 & \pm 0.0 & - \\
\hline $20: 4 n-6$ & 1.1 & \pm 0.0 & 0.6 \\
\hline $22: 4 n-6$ & 0.2 & \pm 0.0 & - \\
\hline $\begin{array}{l}22: 5 n-6 \\
\omega-3\end{array}$ & 0.5 & \pm 0.1 & 0.1 \\
\hline $18: 3 n-3$ & 1.6 & \pm 0.0 & 1.0 \\
\hline $18: 4 n-3$ & 1.7 & \pm 0.0 & 2.8 \\
\hline $20: 3 n-3$ & 0.2 & \pm 0.1 & - \\
\hline $20: 4 n-3$ & 0.9 & \pm 0.1 & 0.9 \\
\hline $20: 5 n-3$ & 7.9 & \pm 0.1 & 15.0 \\
\hline $21: 5 n-3$ & 0.4 & \pm 0.0 & 0.7 \\
\hline $22: 5 n-3$ & 2.3 & \pm 0.0 & 1.6 \\
\hline $22: 6 n-3$ & 14.2 & \pm 0.1 & 10.3 \\
\hline
\end{tabular}

Refined oil numbers represent means \pm standard deviations among five different lots $(n=5)$. 


\subsection{Quality of Fish Meal from Urban Fisheries Biomass}

We compared the chemical properties and qualities of FM from UFB with those of control FM produced from anchoveta. There was less crude protein in FM from UFB than in FM from anchoveta, while there was more ash in FM from UFB. There was little variation between these FMs in the amino-acid profiles (Table 4).

Table 4. Proximate composition and amino-acid profiles of fish meal from urban fisheries biomass.

\begin{tabular}{cccc}
\hline & \multicolumn{2}{c}{ FM from UFB $^{\mathbf{1}}$} & FM from $^{\text {Anchoveta }}{ }^{\mathbf{2}}$ \\
\hline & Proximate & \\
Crude protein & 67.5 & \pm 0.9 & 71.3 \\
Crude fat & 8.0 & \pm 0.5 & 9.8 \\
Ash & 20.3 & \pm 1.3 & 16.4 \\
& Amino Acids $(\%$ dry basis $)$ & \\
Ala & 5.2 & \pm 0.1 & 4.9 \\
Arg & 4.5 & \pm 0.1 & 4.3 \\
Asp & 6.1 & \pm 0.1 & 7.0 \\
Cys & 0.6 & \pm 0.0 & 0.7 \\
Glu & 8.9 & \pm 0.1 & 9.9 \\
Gly & 7.1 & \pm 0.2 & 4.9 \\
His & 2.4 & \pm 0.1 & 2.7 \\
Ile & 2.6 & \pm 0.0 & 3.1 \\
Leu & 4.7 & \pm 0.1 & 5.6 \\
Lys & 5.0 & \pm 0.1 & 5.9 \\
Met & 1.9 & \pm 0.0 & 2.0 \\
Phe & 2.6 & \pm 0.0 & 3.1 \\
Pro & 4.1 & \pm 0.1 & 3.1 \\
Ser & 3.0 & \pm 0.0 & 2.9 \\
Thr & 3.0 & \pm 0.0 & 3.3 \\
Trp & 0.7 & \pm 0.0 & 0.9 \\
Tyr & 2.0 & \pm 0.0 & 3.3 \\
Val & 3.2 & \pm 0.0 & 3.8 \\
\hline
\end{tabular}

Abbreviations: FM, fish meal. Amino-acid profiles were calculated on the condition that the total amino-acid amount was equal to crude protein. ${ }^{1}$ Numbers represent means \pm standard deviations among five different lots $(n=5) .{ }^{2}$ Amino acid profile was obtained from a previous study [37].

Histamine and volatile basic nitrogen (VBN) are indicators of the freshness of raw materials to FM. Although the contents of histamine and VBN in FM from UFB were relatively high compared to anchoveta, it is noteworthy that the standard deviations were large (Table 5). Seasonal changes in these indicators are shown in Figure 3. Except for the hot season of Japan (July-September), less than $100 \mathrm{mg} / 100 \mathrm{~g}$ of histamine and $150 \mathrm{mg} / 100 \mathrm{~g}$ of VBN were detected in almost all samples produced in two years.

Table 5. Indicators of freshness in fish meal from urban fisheries biomass.

\begin{tabular}{cccc}
\hline & \multicolumn{2}{c}{${\text { FM from } \text { UFB }^{\mathbf{1}}}$} & FM from Anchoveta $^{2}$ \\
\hline Histamine $(\mathrm{mg} / 100 \mathrm{~g})$ & 45.5 & \pm 32.6 & 23.0 \\
VBN $(\mathrm{mg} / 100 \mathrm{~g})$ & 112.5 & \pm 33.4 & 90 \\
\hline
\end{tabular}

Abbreviations: FM, fish meal. ${ }^{1}$ Numbers represent means \pm standard deviations among 20 different lots for the whole season in two years $(n=20){ }^{2}$ Values were obtained from a supplier of FM. 


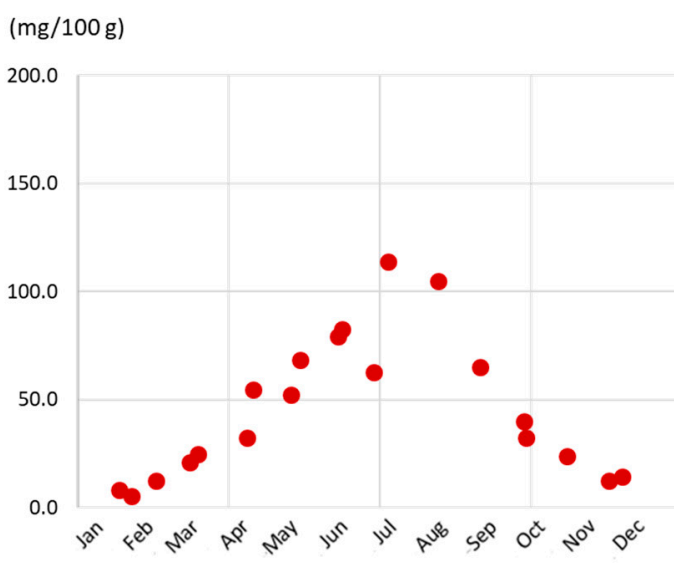

(a)

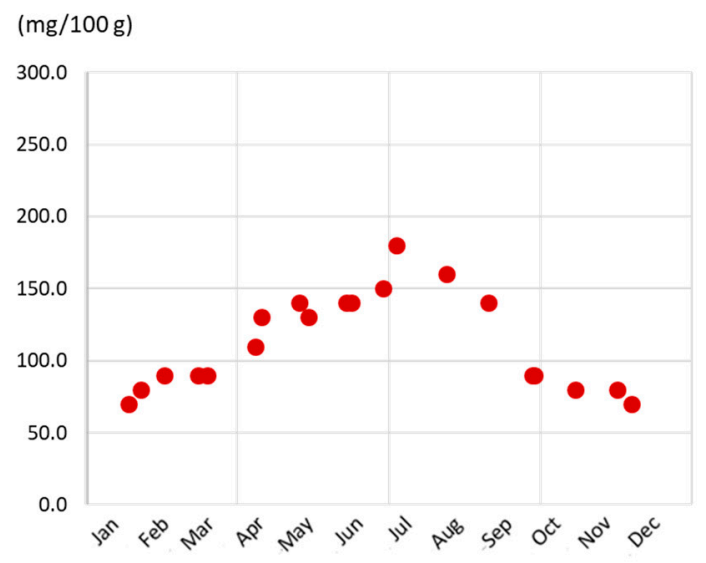

(b)

Figure 3. Seasonal changes of quality of fish meal from the urban fisheries biomass in 2018-2019.

(a) Content of histamine, and (b) volatile basic nitrogen (VBN).

\section{Discussion}

\subsection{Fish Oil and Fish Meal Produced from Fishery By-Products in Japan}

In this study, the system of FO and FM production from UFB in Japan was described, and showed that the qualities of the FO and the FM were comparable to those of control. This study illustrates that the comprehensive utilization of BPs contributes not only to sustainable aquaculture, but to a reduction of food loss and the improvement of food security [38].

To reduce waste from fish, a collection system for BPs and an integrated production of FO and FM are necessary. The food waste of fish and seafood in Europe, North America, Oceania, and industrialized Asia were generated 1.5-1.8 times more in the distribution process than the processing process. In particular, the waste from distribution in industrialized Asia was estimated to be $11 \%$, which is higher than in Europe (9\%), and in North America and Oceania (9\%) [39]. This seems to be due to differences in the seafood supply chain. Although processing is located upstream of the modern supply chain [40], the traditional value chain with dispersive fish processing in downstream areas is still seen in the majority of Asian countries. Therefore, a system which collects fresh BPs from the downstream of the supply chain, for example, from wholesalers, retailers, processors, and restaurants, is needed to reduce food waste.

In Japan, 844,909 tonnes of material were used for the production of FO and FM, and 79.4\% of the total material (670,987 tonnes) were BPs in 2018 [21]. The ratio is much higher than those in other areas, in particular, $47 \%-54 \%$ in Europe, $25 \%-35 \%$ in China, and $30 \%-44 \%$ in Asia, excluding China [17]. This is due to the integrated system of BP collection, producing crude FO and FM, and the refinement of FO. A lack of infrastructure is noted as one of the major elements in the generation of food waste [41]. Although FO and FM production in Japan had relied on Japanese sardine (Sardinops melanostictus) fisheries, stock of the fish rapidly fell to low levels since the early 1990s [42]. Consequently, to secure materials, the infrastructure for collecting BPs has been well developed in Japan.

We focused on the importance of UFB in the study. Since many retail and restaurant are located in populated areas in general, BPs from downstream are well correlated with the population. BPs from downstream accounted for around 70\% of total BPs in Japan [22], and BPs from these industries could not be ignored for reducing food waste. It seems to be caused by a business custom in Japan that fish are conventionally distributed to the consumption area as a whole body and are processed there.

Presently, only Sanki Shiryo Kogyo Co., Ltd. collects UFB in the whole Kanto area, including Tokyo and the suburbs, which is not only the most highly populated area in Japan, but one of the world's most populated areas. From the calculation by the previous study [22], the area generates $28 \%$ of the total BPs in Japan. The company buys $400-500$ tonnes of BPs almost every day from over 
10,000 suppliers (retail, processors, wholesale, and restaurants). The BPs mainly consisted of the heads, guts, and bones, while few fish discards were included. The company sells FM to feed mills and provides oil refineries with crude FO on a daily basis. The oil refineries produce refined oils through a refinement process and sell them to feed mills for aquaculture feedstuff. FO and FM produced by the company accounts for almost $20 \%$ of the total production in Japan. Although AV of the crude FO was much higher than that of control FO, other factors indicating quality were comparable. Moreover, the refinement process significantly improved $\mathrm{AV}$, as well as oxidization indicators, so that the refined FO reached the standard values of FO defined by the Codex Alimentarius Commission [43].

The refinement process was known to be effective to improve the quality of FO from the BPs of the bluefin tuna (Thunnus thynnus), seabass (Dicentrarhus labrax), gilthead seabream (Sparus aurata) [23], and carp (Cyprinus carpio) viscera [24]. POVs of oils from salmon BPs caught in Alaska significantly decreased through the refinement process with activated clay [44]. In contrast, the POV of FO from cobia (Rachycentron canachum) livers were not changed with or without a similar process [45]. Meanwhile, in the production process of crude oil from the maatjes herring (Clupea harengus) [46], the quality was shown to depend on the freshness of the BPs [47]. The extraction method also affects the POV of oils from the yellowfin tuna (Thunnus albacares) BPs [48]. Compared to the FOs from BPs in these previous studies, the refined FOs in this study had comparable or even better quality. In addition, the quality could be guaranteed by the business model, namely, to keep BPs fresh, and to prevent contamination of non-fishery BPs. According to the previous case study of the company, they strictly control the BPs they receive. They require their suppliers to segregate fishery BPs from other wastes, drain the water from BPs, and put BPs in a tank with a lid. They sometimes refuse BPs if suppliers fail to comply with these conditions [49].

Regarding FM, its ash content was higher than that of whole fish meal, and this was likely due to the fact that BPs consisted of a large number of bones and scales. In spite of its high ash content, tuna by-product meals were reported to meet nutritional requirements, and could be used as a replacement of FM in the diet of Korean rockfish (Sebastes schlegeli) [50]. On the contrary, only 25\% of FM could be replaced with salmon head meal, a processing waste from Alaska salmonids in the diet of the red drum (Sciaenops ocellatus). The meal was concluded to be poorly utilized because of its low protein and high fat content [51]. FM from UFB in this study is thought to be a promising feedstuff which can be replaced with FM from whole fish because of their similar nutritional compositions, as long as the freshness of fisheries biomass is maintained. It is noted that UFB could be an alternative and sustainable resource for aquaculture feed, and a highly developed infrastructure like the case in this study realizes the utilization of the biomass.

\subsection{Fish Oil and Fish Meal Produced from Fisheries By-Products in Japan}

To enhance the sustainability and responsibility of aquaculture, traceability of feed sources should be ensured in an FAO guideline which many ecolabels rely on [52]. The improvement of traceability of fishmeal is high on the agenda in the feed industry [53]. The company makes a sales contract individually with their suppliers, that is, retailers, restaurants, wholesalers and processors, which in total amount to over 10,000. Therefore, the sources could be substantially traced, despite the company buying and receiving enormous amounts of BPs-400-500 tonnes in total from over 10,000 suppliers almost every day. However, there are several issues with the FO and FM used for aquaculture feed to be discussed.

The first is an issue of intra-species recycling. Feedstuff made from salmon BPs is prohibited to feed back to the same species in the main salmon-producing countries, including Norway and Chile [6]. Meanwhile, in Asian countries, including Japan, there are no such regulations [20]. Urban fisheries biomass includes various kinds of fish from the consumption area; thus, a possibility of contamination of BPs from the same species as farmed fish cannot be excluded. Although transmissible spongiform encephalopathy (TSE) risk of animal protein recycling has been well discussed [54], there are few studies on the risk in oil. To meet the nutritional requirements of marine cultured fish, utilization 
of omega-3 fatty acids from UFB should be considered. Since the refinement process could remove contaminants from FO, it might make a contribution to reducing the risk.

The second issue is a risk of contamination of BPs from fish species at risk. Regrettably, some fish on the endangered list are distributed for food in the Japanese market. We conducted the risk assessment in this study, and the contamination risk of the bluefin tuna and the Japanese eel was estimated to be $0.63 \%$ (Table 1 ).

The third is a risk of contamination of BPs from IUU (illegal, unreported, and unregulated) fishing. An investigation indicates that $24 \%-36 \%$ of wild-catch fish imports in 2015 originated from IUU fishing due to a lack of IUU traceability standards [55]. BPs from fish on the endangered list or IUU seem to be contained unintentionally in materials of FO and FM from UFB. Segregation of endangered or IUU BPs from the collected biomass is not expected to put no pressure on the fisheries. Strict regulations to stop the trading of endangered or IUU fish products are urgently needed to be introduced in Japan, and they will result in the improved responsibility of aquaculture.

\section{Conclusions}

In this study, we focused on UFB as a promising source of alternative feedstuff through a case study in Japan. The nutrients and qualities of FO and FM from UFB were comparable with those from whole fish. Although it could reduce the fishing pressure on fish targeted for meal and oil production, the problems of intra-species recycling and contamination of endangered fish species and IUU have to be solved from a higher standpoint for sustainable development goals.

Author Contributions: Analysis: M.K. and A.I.; Design of the work, investigation, data analysis, and writing: A.I. All authors have read and agreed to the published version of the manuscript.

Funding: This research was funded by the Japan Seriola Initiative and World Wildlife Fund (WWF) Japan.

Acknowledgments: We would like to thank Go Fujimura (Sanki Shiryo Kogyo Ltd.), Yutaka Hanaoka, and Ayumi Izumi (Nikko Oil \& Fat Co., Ltd.) for kindly providing us with the samples for analysis in this study and for giving us useful information; thanks to Takao Satoh (Kumamoto Industrial Research Institute) and the members of Ehime Institute of Industrial Technology for helping us with the analyses; thanks to Satoshi Maekawa (WWF Japan) for helpful discussions; and thanks to Takeshi Miura for useful technical suggestions.

Conflicts of Interest: The authors declare no conflict of interest.

\section{References}

1. Olsen, R.L.; Hasan, M.R. A limited supply of fishmeal: Impact on future increases in global aquaculture. Trends Food Sci. Technol. 2012, 27, 120-128. [CrossRef]

2. Tacon, A.G.J.; Metian, M. Feed Matters: Satisfying the Feed Demand of Aquaculture. Rev. Fish. Sci. Aquac. 2015, 23, 1-10. [CrossRef]

3. Alder, J.; Campbell, B.; Karpouzi, V.; Kaschner, K.; Pauly, D. Forage Fish: From Ecosystems to Markets. Annu. Rev. Environ. Resour. 2008, 33, 153-166. [CrossRef]

4. Shepherd, J.; Bachis, E. Changing supply and demand for fish oil. Aquac. Econ. Manag. 2014, 18, $395-416$. [CrossRef]

5. Gatlin, D.M.; Barrows, F.T.; Brown, P.; Dabrowski, K.; Gaylord, T.G.; Hardy, R.W.; Herman, E.; Hu, G.; Krogdahl, A.; Nelson, R.; et al. Expanding the utilization of sustainable plant products in aquafeeds: A review. Aquac. Res. 2007, 38, 551-579. [CrossRef]

6. Tacon, A.G.J.; Hasan, M.R.; Subasinghe, R.P. Use of Fishery Resources as Feed Inputs to Aquaculture Development: Trends and Policy Implications. In FAO Fisheries Circular; FAO: Rome, Italy, 2006; Volume 1018.

7. Zhou, Q.-C.; Zhao, J.; Li, P.; Wang, H.-L.; Wang, L.-G. Evaluation of poultry by-product meal in commercial diets for juvenile cobia (Rachycentron canadum). Aquaculture 2011, 322-323, 122-127. [CrossRef]

8. Kureshy, N.; Davis, D.A.; Arnold, C.R. Partial Replacement of Fish Meal with Meat-and-Bone Meal, Flash-Dried Poultry By-Product Meal, and Enzyme-Digested Poultry By-Product Meal in Practical Diets for Juvenile Red Drum. N. Am. J. Aquac. 2000, 62, 266-272. [CrossRef] 
9. Ido, A.; Iwai, T.; Ito, K.; Ohta, T.; Mizushige, T.; Kishida, T.; Miura, C.; Miura, T. Dietary effects of housefly (Musca domestica) (Diptera: Muscidae) pupae on the growth performance and the resistance against bacterial pathogen in red sea bream (Pagrus major) (Perciformes: Sparidae). Appl. Entomol. Zool. 2015, 50, $213-221$. [CrossRef]

10. Ido, A.; Hashizume, A.; Ohta, T.; Takahashi, T.; Miura, C.; Miura, T. Replacement of Fish Meal by Defatted Yellow Mealworm (Tenebrio molitor) Larvae in Diet Improves Growth Performance and Disease Resistance in Red Seabream (Pargus major). Animals 2019, 9, 100. [CrossRef]

11. Hashizume, A.; Ido, A.; Ohta, T.; Thiaw, S.T.; Morita, R.; Nishikawa, M.; Takahashi, T.; Miura, C.; Miura, T. Housefly (Musca domestica) Larvae Preparations after Removing the Hydrophobic Fraction Are Effective Alternatives to Fish Meal in Aquaculture Feed for Red Seabream (Pagrus major). Fishes 2019, 4, 38. [CrossRef]

12. Henry, M.; Gasco, L.; Piccolo, G.; Fountoulaki, E. Review on the use of insects in the diet of farmed fish: Past and future. Anim. Feed Sci. Technol. 2015, 203, 1-22. [CrossRef]

13. Sprague, M.; Betancor, M.B.; Tocher, D.R. Microbial and genetically engineered oils as replacements for fish oil in aquaculture feeds. Biotechnol. Lett. 2017, 39, 1599-1609. [CrossRef] [PubMed]

14. Takeuchi, T. A review of feed development for early life stages of marine finfish in Japan. Aquaculture 2001, 200, 203-222. [CrossRef]

15. Kaneniwa, M. Efficient utilization of aquatic biomass resources. Nippon Suisan Gakkaishi 2009, 75, 93-95. [CrossRef]

16. Stevens, J.R.; Newton, R.W.; Tlusty, M.; Little, D.C. The rise of aquaculture by-products: Increasing food production, value, and sustainability through strategic utilisation. Mar. Policy 2018, 90, 115-124. [CrossRef]

17. Jackson, A.; Newton, R.W. Project to Model the Use of Fisheries By-Products in the Production of Marine Ingredients with Special Reference to Omega 3 Fatty Acids EPA and DHA; IFFO: London, UK, 2016; pp. 1-14.

18. Ghaly, A.E.; Ramakrishnan, V.V.; Brooks, M.S.; Budge, S.M.; Dave, D. Fish processing wastes as a potential source of proteins, amino acids and oils: A critical review. J. Microb. Biochem. Technol. 2013, 5, 107-129.

19. Ytrestøyl, T.; Aas, T.S.; Åsgård, T. Utilisation of feed resources in production of Atlantic salmon (Salmo salar) in Norway. Aquaculture 2015, 448, 365-374. [CrossRef]

20. De Silva, S.S.; Turchini, G.M. Use of wild fish and other aquatic organisms as feed in aquaculture-A review of practices and implications in Asia-Pacific. In Fish as Feed Inputs for Aquaculture: Practices, Sustainability and Implications; Hasan, M.R., Halwart, M., Eds.; FAO: Rome, Italy, 2009; pp. 63-127. ISBN 978-92-5-106419-1.

21. Japan Marine Oil Association. Marine Oil Statistical Yearbook 2018; Japan Marine Oil Association: Tokyo, Japan, 2019.

22. Tarui, Y. Generation and collection of fisheries residue. In Advanced Utilization of Fsheries Resources; Sakaguchi, M., Hirata, T., Eds.; NTS Inc.: Tokyo, Japan, 2005; pp. 15-28. ISBN 4-86043-093-X.

23. Šimat, V.; Vlahovic, J.; Soldo, B.; Skroza, D.; Ljubenkov, I.; Mekinic, I.G. Production and refinement of omega-3 rich oils from processing by-products of farmed fish species. Foods 2019, 8, 125. [CrossRef]

24. Crexi, V.T.; Monte, M.L.; de Souza Soares, L.A.; Pinto, L.A.A. Production and refinement of oil from carp (Cyprinus carpio) viscera. Food Chem. 2010, 119, 945-950. [CrossRef]

25. Japan Oil Chemists' Society. Standard Methods for the Analysis of Fats, Oils and Related Materials: The JOCS Standard Methods for the Analysis of Fats, Oils and Related Materials; Japan Oil Chemists' Society: Tokyo, Japan, 2018; ISBN 978-4-931-24906-6.

26. The Pharmaceutical Society of Japan. Standard Methods of Analysis for Hygienic Chemists: With Commentary; KANEHARA \& CO., LTD.: Tokyo, Japan, 2015; ISBN 978-4-307-47043-8.

27. Läubli, M.W.; Bruttel, P.A. Determination of the oxidative stability of fats and oils: Comparison between the active oxygen method (AOCS Cd 12-57) and the rancimat method. J. Am. Oil Chem. Soc. 1986, 63, 792-795. [CrossRef]

28. The Consumer Affairs Agency in Japan. Food Labelling. Available online: https://www.caa.go.jp/en/policy/ food_labeling/ (accessed on 23 February 2020).

29. AOAC International. Official Methods of Analysis of AOAC International, 20th ed.; Latimer, W.G., Ed.; AOAC International: Gaithersburg, MD, USA, 2016; ISBN 0935584870.

30. Tamase, K.; Kitada, Y.; Mizobuchi, M.; Sasaki, M. Simultaneous Determination of Histidine and Histamine in Fish by High Performance Liquid Chromatography. Food Hyg. Saf. Sci. (Shokuhin Eiseigaku Zasshi) 1984, 25, 525-529_1. [CrossRef] 
31. The Ministry of Agriculture Foresty and Fisheries of Japan. Feed Analysis Standards. Available online: http://www.famic.go.jp/ffis/feed/bunseki/bunsekikijun.html (accessed on 23 February 2020).

32. Ministry of Internal Affairs and Communications. System of Social and Demographic Statistics. Available online: https://www.e-stat.go.jp/ (accessed on 6 February 2020).

33. Collette, B.; Chang, S.-K.; Di Natale, A.; Fox, W.; Juan Jorda, M.; Miyabe, N.; Nelson, R.; Uozumi, Y.; Wang, S. Thunnus Maccoyii. Available online: https://dx.doi.org/10.2305/IUCN.UK.2011-2.RLTS.T21858A9328286.en (accessed on 26 February 2020).

34. Jacoby, D.; Gollock, M. Anguilla japonica. Available online: http://dx.doi.org/10.2305/IUCN.UK.2014-1.RLTS. T166184A1117791.en (accessed on 26 February 2020).

35. The Ministry of Agriculture Foresty and Fisheries of Japan. Census of Fisheries. Available online: https://www.e-stat.go.jp/ (accessed on 6 February 2020).

36. Ministry of Finance JAPAN. Trade Statistics of Japan. Available online: https://www.e-stat.go.jp/ (accessed on 6 February 2020).

37. Japan Marine Oil Association. Marine Oil Statistical Yearbook 2015; Japan Marine Oil Association: Tokyo, Janpan, 2016.

38. Nellemann, C.; MacDevette, M.; Manders, T.; Eickhout, B.; Svihus, B.; Prins, A.G.; Kaltenborn, B.P. The Environmental Food Crisis-The Environment's Role in Averting Future Food Crises; UNEP/GRID-Arendal: Arendal, Norway, 2009; ISBN 9788277010540.

39. Gustavsson, J.; Cederberg, C.; Sonesson, U.; van Otterdijk, R.; Meybeck, A. Global Food Losses and Food Waste_Extent, Causes and Prevention; FAO: Rome, Italy, 2011; ISBN 9789251072059.

40. Belchior, C.; Boteler, B.; Jansen, H.; Piet, G. Seafood in Europe: A Food System Approach for Sustainability; European Environment Agency (EEA): Luxembourg, 2016.

41. Parfitt, J.; Barthel, M.; MacNaughton, S. Food waste within food supply chains: Quantification and potential for change to 2050. Philos. Trans. R. Soc. B Biol. Sci. 2010, 365, 3065-3081. [CrossRef] [PubMed]

42. Ishida, Y.; Funamoto, T.; Honda, S.; Yabuki, K.; Nishida, H.; Watanabe, C. Management of declining Japanese sardine, chub mackerel and walleye pollock fisheries in Japan. Fish. Res. 2009, 100, 68-77. [CrossRef]

43. Codex Alimentarius Commision. Standard for Fish Oils; CODEX STAN: Rome, Italy, 2017.

44. Huang, J.; Sathivel, S. Purifying salmon oil using adsorption, neutralization, and a combined neutralization and adsorption process. J. Food Eng. 2010, 96, 51-58. [CrossRef]

45. Kuo, C.H.; Liao, H.Z.; Wang, Y.H.; Wang, H.M.D.; Shieh, C.J.; Tseng, C.Y. Highly efficient extraction of EPA/DHA-enriched oil from cobia liver using homogenization plus sonication. Eur. J. Lipid Sci. Technol. 2017, 119, 1-8. [CrossRef]

46. Aidos, I.; Van der Padt, A.; Boom, R.M.; Luten, J.B. Upgrading of maatjes herring byproducts: Production of crude fish oil. J. Agric. Food Chem. 2001, 49, 3697-3704. [CrossRef]

47. Aidos, I.; Van Der Padt, A.; Boom, R.M.; Luten, J.B. Quality of crude fish oil extracted from herring byproducts of varying states of freshness. J. Food Sci. 2003, 68, 458-465. [CrossRef]

48. Nazir, N.; Diana, A.; Sayuti, K. Physicochemical and Fatty Acid Profile of Fish Oil from Head of Tuna (Thunnus albacares) Extracted from Various Extraction Method. Int. J. Adv. Sci. Eng. Inf. Technol. 2017, 7, 709-715. [CrossRef]

49. Kobayashi, T.; Takeya, H. Fish Discard Collection System: The Profitability and Complementary Role of the Public Sector in Food Recycling. Agric. Mark. J. Japan 2003, 12, 21-31.

50. Jeon, G.H.; Kim, H.S.; Myung, S.H.; Cho, S.H. The effect of the dietary substitution of fishmeal with tuna by-product meal on growth, body composition, plasma chemistry and amino acid profiles of juvenile Korean rockfish (Sebastes schlegeli). Aquac. Nutr. 2014, 20, 753-761. [CrossRef]

51. Li, P.; Wang, X.; Hardy, R.W.; Gatlin, D.M. Nutritional value of fisheries by-catch and by-product meals in the diet of red drum (Sciaenops ocellatus). Aquaculture 2004, 236, 485-496. [CrossRef]

52. FAO. Technical Guidelines on Aquaculture Certification; FAO: Rome, Italy, 2011; ISBN 9789250069128.

53. Huntington, T.C.; Hasan, M.R. Fish as feed inputs for aquaculture: Practices, sustainability and implications: A global synthesis. In Fish as Feed Inputs for Aquaculture: Practices, Sustainability and Implications; Hasan, M.R., Halwart, M., Eds.; FAO Fisheries and Aquaculture Technical Paper No. 518; FAO: Rome, Italy, 2009; pp. 1-61. 
54. Jędrejek, D.; Levic, J.; Wallace, J.; Oleszek, W. Animal by-products for feed: Characteristics, European regulatory framework, and potential impacts on human and animal health and the environment. J. Anim. Feed Sci. 2016, 25, 189-202. [CrossRef]

55. Pramod, G.; Pitcher, T.J. Estimates of illegal and unreported seafood imports to Japan. Mar. Policy 2017, 84, 42-51. [CrossRef] article distributed under the terms and conditions of the Creative Commons Attribution (CC BY) license (http://creativecommons.org/licenses/by/4.0/). 